\title{
Article \\ Helminths in Myomorph Rodents (Rodentia, Myomorpha) from the National Park "Smolny" and Its Surroundings (European Russia)
}

\author{
Nadezhda Kirillova ${ }^{1}$, Alexander Ruchin ${ }^{2, *}$ (I) and Alexander Kirillov ${ }^{1}$ \\ 1 Samara Federal Research Center RAS, Institute of Ecology of Volga River Basin RAS, 445003 Togliatti, Russia; \\ ievbras2005@mail.ru (N.K.); parasitolog@yandex.ru (A.K.) \\ 2 Joint Directorate of the Mordovia State Nature Reserve and National Park "Smolny", 430005 Saransk, Russia \\ * Correspondence: ruchin.alexander@gmail.com
}

Citation: Kirillova, N.; Ruchin, A.; Kirillov, A. Helminths in Myomorph Rodents (Rodentia, Myomorpha) from the National Park "Smolny" and Its Surroundings (European Russia). Forests 2021, 12, 1510. https:// doi.org/10.3390/f12111510

Academic Editor: Timothy A. Martin

Received: 17 September 2021

Accepted: 29 October 2021

Published: 1 November 2021

Publisher's Note: MDPI stays neutral with regard to jurisdictional claims in published maps and institutional affiliations.

Copyright: (c) 2021 by the authors. Licensee MDPI, Basel, Switzerland. This article is an open access article distributed under the terms and conditions of the Creative Commons Attribution (CC BY) license (https:// creativecommons.org/licenses/by/ $4.0 /)$.

\begin{abstract}
The National Park "Smolny" is a large forest area, located in the center of European Russia. The helminth fauna of myomorph rodents was studied for the first time within the National Park in 2018-2020. Rodents were examined by the method of complete helminthological dissection. A total of 30 species of parasites were recorded in 11 rodent species: 6 trematodes, 11 cestodes and 13 nematodes. The trematode Plagiorchis maculosus (Rudolphi, 1802) was found in Clethrionomys glareolus (Schreber, 1780) from the Russian fauna for the first time. Clethrionomys glareolus and Microtus arvalis (Pallas, 1779) are new hosts for P. maculosus and metacestode Versteria mustelae (Gmelin, 1790), respectively. The most widespread and eurybiont rodent species have the most diverse and rich helminth fauna, such as C/ glareolus (14 species), Apodemus agrarius (Pallas, 1771) (12) and Sylvaemus uralensis (Pallas, 1811) (10). The helminth fauna is less diverse in Sylvaemus flavicollis (Melchior, 1834), M. arvalis (7 species each), Microtus agrestis (Linnaeus, 1761) (5), Microtus subterraneus (de Selys-Longchamps, 1836) (3), Sicista betulina (Pallas, 1779) (2) and Arvicola amphibius (Linnaeus, 1758) (1). Comparative analysis the helminth fauna of small rodents from the National Park "Smolny" with micromammals from other regions of European Russia revealed that the high similarity with other areas reaches the helminth fauna of M. subterraneus, S. flavicollis, S. uralensis, S. betulina, A. amphibius and M. agrestis.
\end{abstract}

Keywords: protected area; parasitic worms; micromammals; Nematoda; Cestoda; Trematoda; biodiversity

\section{Introduction}

Parasitic organisms are an integral part of natural biocenoses. They play an important role in the biosphere and act as one of the factors of biodiversity formation [1-7]. Helminths live in all vertebrates, including small rodents. Their species composition, age and seasonal infection rates serve to understand the changes that may occur in ecosystems [8-10].

The study of helminths of wild mammals in protected areas is of particular interest, because, the species diversity of both animal hosts and their parasites is most fully preserved here as a result of the special regime. In the context of global anthropogenic transformations of natural ecosystems, only protected areas are the most favorable places for animals to live in [11-15], the purpose of which is to preserve the biodiversity of forest ecosystems [16-21].

There are more than 300 protected areas of federal significance located in the territory of European Russia. Most of them are territories with large forest areas with rich biodiversity. Despite the long history of flora and fauna research in the Russian protected areas, the inventory of biodiversity in their territories is still one of the most actual purposes [22-26].

In forest ecosystems, the most representative and widespread mammal group is small wild rodents. Despite the wide distribution and high number of myomorph rodents, a long 
history of studying their helminth fauna, there are still regions in the territory of European Russia, including protected areas, where such research has not been carried out.

Considering that full-scale helminthological studies of vertebrates in the National Park "Smolny" have not previously been carried out, the trend of parasitological research associated with the inventory of animal helminth fauna as one of the stages of the inventory of the fauna of protected areas, monitoring and preserving biological diversity is relevant $[9,27-34]$.

Settlements, livestock farms and agricultural landscapes are located around the territory of the National Park and on its borders. In such conditions, the functioning of natural focal helminthic zoonoses is possible. Meanwhile, myomorph rodents play an important role in the circulation of helminths of vertebrates at the highest trophic levelspredatory mammals and birds. Small rodents are involved in maintaining natural foci of helminthiasis-dangerous diseases of humans, domestic and wild animals [19,35-39].

Data on helminths of small mammals from the National Park "Smolny" is known only from one research and includes data on three species of parasites in Microtus subterraneus (de Selys-Longchamps, 1836) [40]. The purpose of this article is to study the helminth fauna in myomorph rodents from the National Park "Smolny".

\section{Materials and Methods}

\subsection{Study Area}

The National Park "Smolny" has an area of $363.85 \mathrm{~km}^{2}$ and is located in the northwestern part of the Volga Upland, in the center of the Russian Plain. The flora is very rich and peculiar, which is determined by the location of the park on the border of mixed, broadleaved forests and forest-steppe [41]. Its coniferous forests are formed by Pinus sylvestris L., and Picea abies (L.) with a predominance of mixed coniferous-deciduousor subtaiga forests. There are no pure spruce forests, since the spruce is located on the southern border of its natural range. Most often these are spruce forests with an admixture of Pinus sylvestris, Betula pendula Roth and other hardwoods [41].

Broadleaved forests within the park are formed by Quercus robur L., Tilia cordata Mill., Acer platanoides L., occasionally there are Fraxinus excelsior L. and Ulmus laevis Pall. Corylus avellana (L.), Lonicera xylosteum L., Euonymus verrucosus Scop. are common for the undergrowth of oak forests. Linden and oak-linden forests often grow on the slopes of ravines and steep banks of valleys of forest rivers. Birch forests are widespread and often represent communities with single-species stands. Alder forests are found mainly in lowlands of river valleys, as well as along the ravines, along the banks of streams and lakes. There are many rivers, streams, lakes and swamps on the territory of the park. There are small plain-type rivers with a small drainage basin [41].

The variety of natural conditions determines the richness of the flora and fauna of the National Park "Smolny". The recent fauna includes 18 species of rodents, including 15 species of myomorph rodents. These include the Clethrionomys glareolus (Schreber, 1780), Microtus arvalis (Pallas, 1779), Microtus agrestis (Linnaeus, 1761), Arvicola amphibius (Linnaeus, 1758), Apodemus agrarius (Pallas, 1771), Sylvaemus flavicollis (Melchior, 1834), Sylvaemus uralensis (Pallas, 1811), Mus musculus Linnaeus, 1758, Micromys minutus (Pallas, 1771), Sicista betulina (Pallas, 1779), Rattus norvegicus (Berkenhout, 1769), Myoxus glis Linnaeus, 1766, Dryomys nitedula (Pallas, 1778), Muscardinus avellanarius Linnaeus, 1758 [41]. Recently, we have recorded the habitation of another rodent species-M. subterraneus [42].

\subsection{Trapping of Rodents}

Myomorph rodents was studied in 15 trapping stations of the National Park "Smolny". Figure 1 shows the study sites of the helminth fauna in micromammals. 


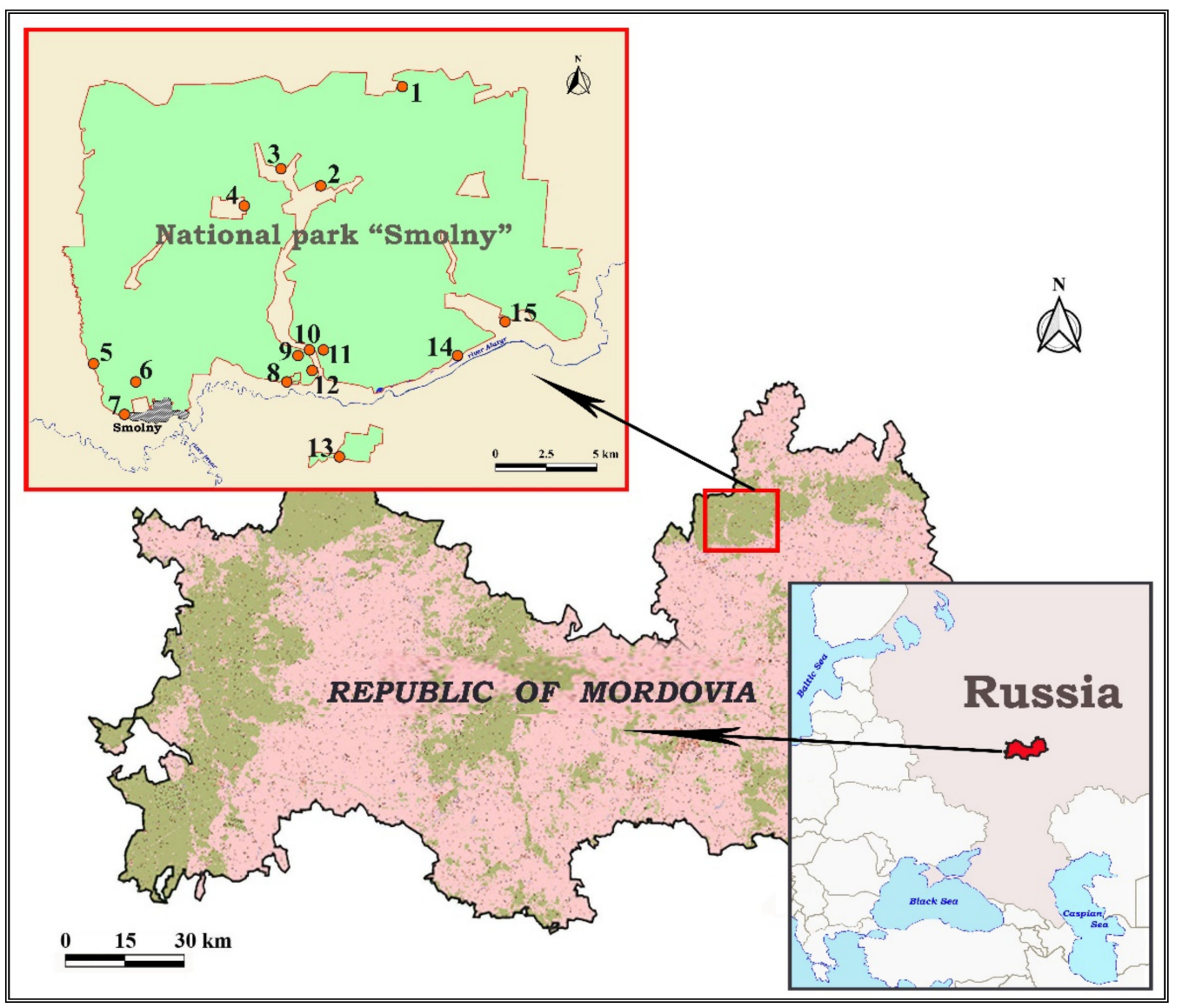

Figure 1. A schematic map of rodent trapping stations in the National Park "Smolny". Red circles in the map showed the rodent trapping places. 1-Lesnoy village, 2-Orlovo Gnezdo site, 3-Obrezki village, 4-Semenovka village, 5-Malye Ichalki village, 6-Tashkinskiy pond, 7-Gorkovskiy cordon, 8-vicinity of sanatorium "Alatyr", 9-Kuzaley Stream, 10-river Kalysha, 11-Kuznal Stream, 12-94th forest compartment of Kemlyanskoye forestry, 13-Troitskiy site, 14-Lake Mitryashki, 15-Ashnya River floodplain.

Within the National Park, trapping sessions of small rodents took place in May-August 2018-2020. Myomorph rodents were captured using spring metal snap traps $(120 \times 55 \mathrm{~mm})$. Trap lines of 20 snap traps, separated by $10-\mathrm{m}$ intervals, were located along the banks of small rivers and streams, forest edges, in fields and meadows. Snap traps baited with rye bread fried in sunflower seed oil. Trapping was conducted for five consecutive days in each locality.

The material for parasitological research was obtained as a result of work on accounting for the number of small rodents. They are regularly counted according to the research topics of the Federal State Budgetary Institution "Reserved Mordovia" ("Zapovednaya Mordovia") in 2018-2020. The research theme, trapping and handling procedures were approved by the Ministry of Natural Resources and Ecology of Russia.

Our research was conducted in compliance with the ethical standards of humane treatment of animals in accordance with the recommended standards described by the Directive of the European Parliament and of the Council of the European Union of 22 September 2010 "On the protection of animals used for scientific purposes" (EU Directive 2010/63/EU) [43]. Trapped rodents were killed by percussive blow to the head. Then the species, sex and age of the animals were identified. 


\subsection{Parasite Examination}

Rodents were examined by the method of complete helminthological dissection $[44,45]$. Helminths were collected and fixed in $70 \%$ ethanol. Trematodes and cestodes were stained with aceto-carmine, cleared in clove oil, and mounted in Canada balsam. Nematodes were translutened in lactic acid and mounted in Glycerin-Jelly [44,45]. The helminth identification was carried out in the Laboratory of Population Ecology of the Institute of Ecology of the Volga Basin of the Russian Academy of Sciences (Togliatti).

The helminth species was identified mainly according to the works of Ryzhikov with co-authors [46,47] and Genov [48]. For species identifying of cestodes, we also used the articles of Makarikov, Tkach [49] (for Hymenolepis spp.), Haukisalmi [50] (for Anoplocephaloides spp.) and Haukisalmi et al. [51] (for Catenotaenia spp.). To identify the trematodes, were used the monographs of Dawes [52], Sharpilo, Iskova [53] (for Plagiorchis spp.) and Kirillov with co-authors [54]. Trichuris nematodes were identified according Feliu et al. [55]. The voucher specimens of parasitic helminths are stored in Parasitological collection of the Institute of Ecology of Volga Basin of RAS, Togliatti, Russia (IEVB RAS). The helminth taxonomy is given according to the Fauna Europaea [56] and Global Cestode Database [57].

\subsection{Data Analysis}

To characterize the infestation of rodents with parasites, the following indices were used: the prevalence of invasion $(\mathrm{P}, \%)$, the intensity range (IR, specimen.) and the mean abundance (MA). For parasites, the following features are given: Latin name, the general geographical distribution, the detection sites, host species in the studied territory.

The Shannon index $\left(H^{\prime}\right)$ was calculated to determine the species diversity of helminths of myomorph rodents. The validity of the differences between the Shannon index value was evaluated using the Student's $t$-test [58]. The differences were considered significant at $p<0.05$. The dominance of individual species in the helminth fauna was determined using the Palia-Kovnatsky index of dominance (D) [59]:

$$
D=P\left(n_{i} / \sum n_{i}\right),
$$

where $P$ is the prevalence of invasion, $\% ; n_{i}$ is the number of specimens of the $i$ species. The parasite dominance groups were considered as following: 10-100-dominants, 1-10subdominants, 0.001-1.000-adominants.

The similarity between the helminth compositions was evaluated by the Morisita's overlap index $(\mathrm{Cm})$. The degree of similarity is following: 0-0.33-low; 0.34-0.66-medium; $0.67-1$ - high. Statistical data processing was performed using the software packages PAST 2.16 (Oslo, Norway) [60] and Microsoft Excel (2003) 11.5612.5606 (Redmond, USA).

\section{Results}

\subsection{Trapping Rodent Results}

From the territory of the National Park "Smolny" and in its vicinity, 1275 individuals of 11 species of Rodentia were caught, namely: C. glareolus (420), M. arvalis (26), M. agrestis (11), M. subterraneus (15), A. amphibius (9), A. agrarius (216), S. flavicollis (263), S. uralensis (309), S. betulina (4), M. musculus (1) and M. minutus (1) (Table 1). 
Table 1. Number of small rodents captured in the National Park "Smolny" in 2018-2020.

\begin{tabular}{|c|c|c|c|c|c|c|c|c|c|c|c|c|c|c|c|}
\hline Rodent Species & $1^{1}$ & 2 & 3 & 4 & 5 & 6 & 7 & 8 & 9 & 10 & 11 & 12 & 13 & 14 & 15 \\
\hline & \multicolumn{15}{|c|}{2018} \\
\hline Clethrionomys glareolus & $0^{2}$ & -3 & 71 & - & - & - & - & 4 & - & - & - & - & - & 36 & - \\
\hline Microtus agrestis & 0 & - & 3 & - & - & - & - & 0 & - & - & - & - & - & 0 & - \\
\hline Arvicola amphibius & 0 & - & 7 & - & - & - & - & 0 & - & - & - & - & - & 0 & - \\
\hline Apodemus agrarius & 0 & - & 27 & - & - & - & - & 0 & - & - & - & - & - & 23 & - \\
\hline Sylvaemus flavicollis & 3 & - & 8 & - & - & - & - & 0 & - & - & - & - & - & 8 & - \\
\hline \multirow[t]{2}{*}{ Sylvaemus uralensis } & 0 & - & 10 & - & - & - & - & 0 & - & - & - & - & - & 15 & - \\
\hline & \multicolumn{15}{|c|}{2019} \\
\hline Clethrionomys glareolus & - & - & 69 & - & - & - & - & - & 10 & 14 & 5 & - & - & 64 & 5 \\
\hline Microtus arvalis & - & - & 7 & - & - & - & - & - & 2 & 0 & 5 & - & - & 1 & 9 \\
\hline Microtus agrestis & - & - & 5 & - & - & - & - & - & 0 & 0 & 0 & - & - & 2 & 2 \\
\hline Microtus subterraneus & - & - & 8 & - & - & - & - & - & 1 & 0 & 0 & - & - & 0 & 0 \\
\hline Apodemus agrarius & - & - & 40 & - & - & - & - & - & 15 & 8 & 1 & - & - & 37 & 49 \\
\hline Sylvaemus flavicollis & - & - & 35 & - & - & - & - & - & 4 & 3 & 5 & - & - & 18 & 3 \\
\hline Sylvaemus uralensis & - & - & 38 & - & - & - & - & - & 15 & 15 & 10 & - & - & 36 & 16 \\
\hline Mus musculus & - & - & 0 & - & - & - & - & - & 0 & 0 & 0 & - & - & 1 & 0 \\
\hline \multirow[t]{2}{*}{ Micromys minutus } & - & - & 1 & - & - & - & - & - & 0 & 0 & 0 & - & - & 0 & 0 \\
\hline & \multicolumn{15}{|c|}{2020} \\
\hline Clethrionomys glareolus & - & 14 & 16 & 0 & 30 & 15 & 16 & - & 0 & 0 & 0 & 0 & 21 & 18 & 12 \\
\hline Microtus arvalis & - & 0 & 2 & 0 & 0 & 0 & 0 & - & 0 & 0 & 0 & 0 & 0 & 0 & 0 \\
\hline Microtus subterraneus & - & 0 & 6 & 0 & 0 & 0 & 0 & - & 0 & 0 & 0 & 0 & 0 & 0 & 0 \\
\hline Arvicola amphibius & - & 0 & 1 & 1 & 0 & 0 & 0 & - & 0 & 0 & 0 & 0 & 0 & 0 & 0 \\
\hline Apodemus agrarius & - & 1 & 5 & 0 & 0 & 0 & 0 & - & 1 & 0 & 0 & 0 & 3 & 1 & 2 \\
\hline Sylvaemus flavicollis & - & 17 & 15 & 0 & 26 & 27 & 16 & - & 4 & 6 & 5 & 10 & 18 & 19 & 13 \\
\hline Sylvaemus uralensis & - & 18 & 18 & 0 & 29 & 20 & 14 & - & 5 & 3 & 10 & 0 & 3 & 22 & 12 \\
\hline Sicista betulina & - & 0 & 4 & 0 & 0 & 0 & 0 & - & 0 & 0 & 0 & 0 & 0 & 0 & 0 \\
\hline
\end{tabular}

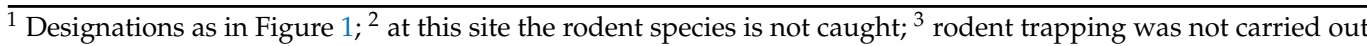
at this site.

\subsection{Helminth Fauna of Small Rodents}

In total, 30 species of parasitic worms were identified in the studied species of small rodents from the National Park "Smolny": 11 cestodes, 6 trematodes and 13 nematodes (Table 2). We did not find any parasites in single specimens of M. musculus and M. minutus. In the vicinity of Semenovka village (Figure 1, site 4), only one individual of $A$. amphibious was caught, which turned out to have no helminths.

Most of the parasites registered in micromammals are represented by adult forms26 species. At the larval stage, only four cestode species are parasitized. For the metacestodes Taenia martis Zeder, 1803, Hydatigera taeniaeformis (Batsch, 1786) s. 1. and Versteria mustelae (Gmelin, 1790), small rodents serve as intermediate hosts. For the cestode larva of Dilepis undula (Schrank, 1788) rodents are paratenic hosts. 
Table 2. List of identified helminth species and their distribution among myomorph rodent hosts from the National Park "Smolny" (2018-2020).

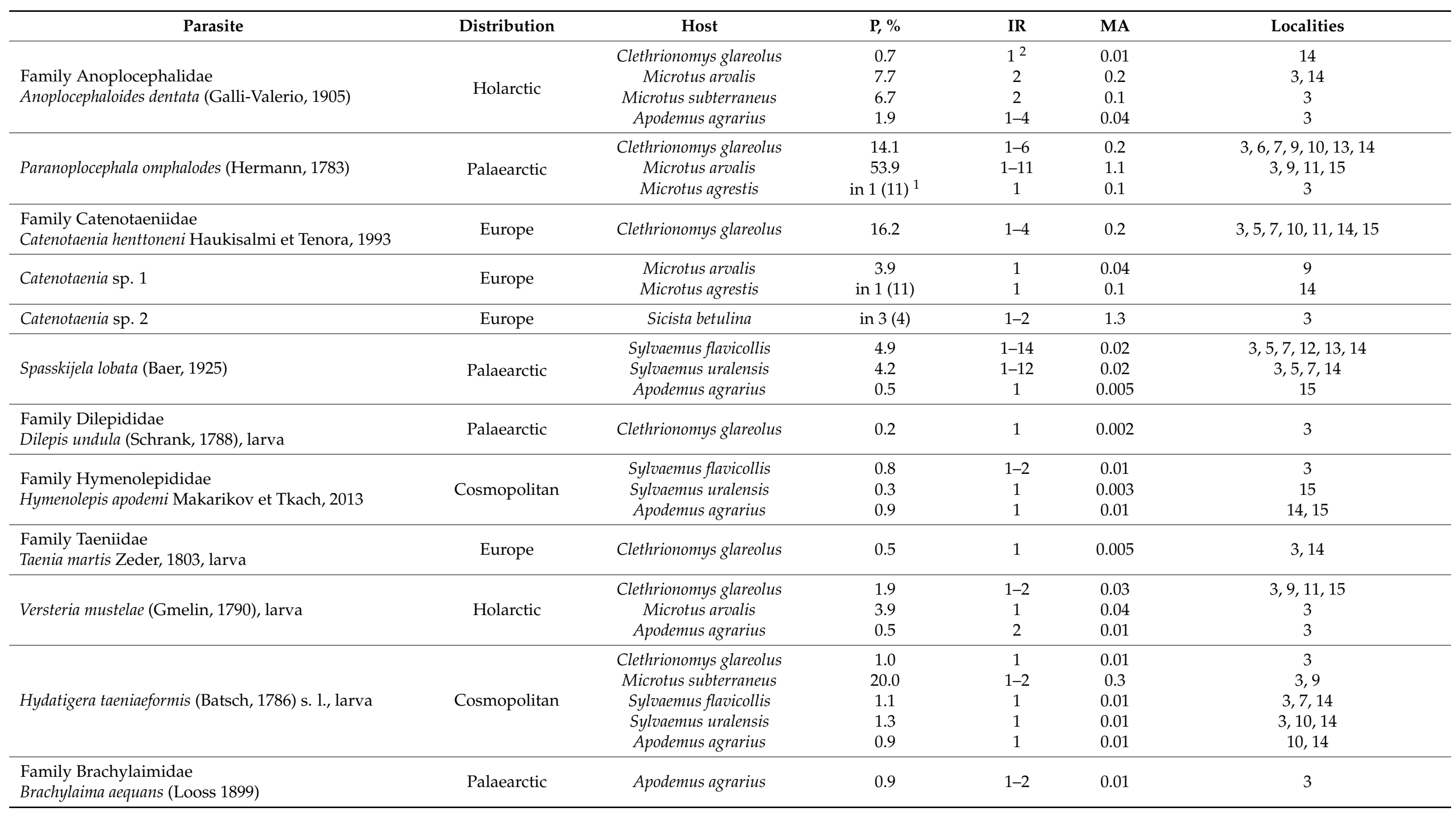


Table 2. Cont.

\begin{tabular}{|c|c|c|c|c|c|c|}
\hline Parasite & Distribution & Host & $\mathbf{P}, \%$ & IR & MA & Localities \\
\hline \multirow{3}{*}{$\begin{array}{l}\text { Family Plagiorchiidae } \\
\text { Plagiorchis elegans (Rudolphi, 1802) }\end{array}$} & \multirow{3}{*}{ Holarctic } & Sylvaemus flavicollis & 3.4 & $1-6$ & 0.12 & $6,14,15$ \\
\hline & & Sylvaemus uralensis & 7.8 & $1-51$ & 0.4 & $3,11,14,15$ \\
\hline & & Apodemus agrarius & 14.4 & $1-27$ & 0.8 & 14,15 \\
\hline Plagiorchis maculosus (Rudolphi, 1802) & Cosmopolitan & Clethrionomys glareolus & 0.2 & 3 & 0.01 & 14 \\
\hline $\begin{array}{l}\text { Family Dicrocoeliidae } \\
\text { Brachylecithum rodentini Agapova, } 1955\end{array}$ & Palaearctic & Clethrionomys glareolus & 1.7 & $2-15$ & 0.1 & 3,8 \\
\hline Corrigia vitta (Dujardin, 1845) & Palaearctic & Sylvaemus uralensis & 1.3 & $1-2$ & 0.02 & 14 \\
\hline $\begin{array}{l}\text { Family Echinostomatidae } \\
\text { Echinostoma miyagawai Ishii, } 1932\end{array}$ & Palaearctic & Apodemus agrarius & 3.7 & $1-2$ & 0.06 & 14,15 \\
\hline Family Trichuridae & \multirow{3}{*}{ Palaearctic } & Clethrionomys glareolus & 1.0 & $1-2$ & 0.07 & 3 \\
\hline Trichuris arvicolae Feliu, Spakulova, Casanova, & & Microtus arvalis & 3.9 & 1 & 0.04 & 14 \\
\hline Renaud, Morand, Hugot, Santalla et Durand, 2000 & & Microtus agrestis & in $1(11)$ & 1 & 0.1 & 15 \\
\hline Trichuris muris (Schrank, 1788) & Palaearctic & Sylvaemus uralensis & 0.3 & 1 & 0.003 & 9 \\
\hline $\begin{array}{l}\text { Family Heligmosomidae } \\
\text { Heligmosomoides glareoli (Baylis, 1928) }\end{array}$ & Palaearctic & Clethrionomys glareolus & 1.4 & $1-3$ & 0.02 & $3,5,14$ \\
\hline \multirow{3}{*}{ Heligmosomoides laevis (Dujardin, 1845) } & \multirow{3}{*}{ Palaearctic } & Microtus arvalis & 7.7 & $2-3$ & 0.2 & 3 \\
\hline & & Microtus agrestis & in $3(11)$ & $2-4$ & 0.7 & $3,14,15$ \\
\hline & & Microtus subterraneus & 20.0 & $1-2$ & 0.3 & 3 \\
\hline \multirow{3}{*}{ Heligmosomoides polygyrus (Dujardin, 1845) } & \multirow{3}{*}{ Palaearctic } & Sylvaemus flavicollis & 48.7 & $1-83$ & 0.5 & $2,3,5,6,7,10,11,12,13,14,15$ \\
\hline & & Sylvaemus uralensis & 29.4 & $1-71$ & 2.4 & $2,3,5,6,7,9,10,11,13,14$ \\
\hline & & Apodemus agrarius & 2.8 & $1-2$ & 0.04 & 14,15 \\
\hline Heligmosomum mixtum Schulz, 1954 & Palaearctic & Clethrionomys glareolus & 59.8 & $1-27$ & 2.7 & $2,3,5,6,7,8,9,10,11,12,13,14,15$ \\
\hline \multirow{4}{*}{$\begin{array}{l}\text { Family Spirocercidae } \\
\text { Mastophorus muris (Gmelin, 1790) }\end{array}$} & \multirow{4}{*}{ Cosmopolitan } & Sicista betulina & in $1(4)$ & 5 & 1.3 & 3 \\
\hline & & Clethrionomysglareolus & 2.9 & $1-13$ & 0.09 & 3,7 \\
\hline & & Sylvaemus uralensis & 0.3 & 1 & 0.003 & 3 \\
\hline & & Apodemus agrarius & 0.5 & 1 & 0.005 & 15 \\
\hline $\begin{array}{l}\text { Family Heterakidae } \\
\text { Heterakis spumosa Schneider, } 1866\end{array}$ & Cosmopolitan & Apodemus agrarius & 15.3 & $1-16$ & 0.5 & $3,9,10,14,15$ \\
\hline
\end{tabular}


Table 2. Cont.

\begin{tabular}{|c|c|c|c|c|c|c|}
\hline Parasite & Distribution & Host & $\mathbf{P}, \%$ & IR & MA & Localities \\
\hline $\begin{array}{l}\text { Family Oxyuridae } \\
\text { Syphacia agraria Sharpilo, } 1973\end{array}$ & Palaearctic & Apodemus agrarius & 28.7 & $1-62$ & 4.4 & $3,9,10,11,14,15$ \\
\hline Syphacia nigeriana Baylis, 1928 & Holarctic & Microtus arvalis & 11.5 & $11-31$ & 2.2 & 14,15 \\
\hline \multirow{2}{*}{ Syphacia obvelata (Rudolphi, 1802) } & \multirow{2}{*}{ Cosmopolitan } & Sylvaemus flavicollis & 12.9 & $1-190$ & 5.2 & $1,3,5,6,10,12,13,14,15$ \\
\hline & & Sylvaemus uralensis & 21.7 & $2-340$ & 8.2 & $3,5,6,7,9,10,11,14,15$ \\
\hline Syphacia petrusewiczi Bernard, 1966 & Holarctic & Clethrionomysglareolus & 13.6 & $3-600$ & 14.9 & $3,5,7,11,13,14,15$ \\
\hline \multirow{2}{*}{ Syphacia stroma (Linstow, 1884) } & \multirow{2}{*}{ Palaearctic } & Sylvaemus flavicollis & 51.3 & $1-450$ & 21.1 & $1,2,3,5,11,13,14$ \\
\hline & & Sylvaemus uralensis & 9.7 & $1-110$ & 1.3 & $3,5,6,14$ \\
\hline
\end{tabular}

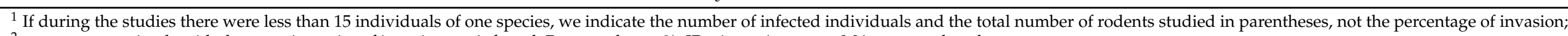

2 one or more animals with the same intensity of invasion are infected; $\mathrm{P}$ - prevalence; $\%$, IR—intensity range; MA—mean abundance. 
In C. glareolus, 14 species of parasites belonging to the following systematic groups were found: 2 trematodes, 7 cestodes and 5 nematodes (Table 2). Two of those species are host-specific parasites of C. glareolus (Heligmosomoides glareoli (Baylis, 1928) and Syphacia petrusewiczi Bernard, 1966). Four helminth species belong to specific rodent parasites of the subfamily Arvicolinae (Anoplocephaloides dentata (Galli-Valerio, 1905), Paranoplocephala omphalodes (Hermann, 1783), Catenotaenia henttoneni Haukisalmi et Tenora, 1993 and Trichuris arvicolae Feliu, Spakulova, Casanova, Renaud, Morand, Hugot, Santalla et Durand, 2000). Six species (the metacestodes T. martis, V. mustelae, H. taeniaeformis s. 1., the trematode Brachylecithum rodentini Agapova, 1955, the nematodes Heligmosomum mixtum Schulz, 1954 and Mastophorus muris (Gmelin, 1790)) recorded in C. glareolus are common parasites of myomorph rodents. Facultative parasites of the vole include Plagiorchis maculosus (Rudolphi, 1802) and D. undula, larva. The general helminth prevalence of $C$. glareolus accounted for $73.3 \%$, the mean abundance was 18.4. There are mainly cestodes, represented by both adult and larval forms, in the helminth fauna of $C$. glareolus. Cestodes account for half of the total number of parasite species. The infestation of $C$. glareolus with cestodes is relatively low $(32.9 \%, 0.5)$. Parameters of rodent invasion by mature cestodes was $31.2 \%, 0.5$; larval stages of cestodes- $3.3 \%, 0.04$. The nematode fauna of $C$. glareolus is represented by five species. Four of them have a direct life cycle, without changing hosts. One species-M. muris has a complex life cycle. The infestation of $C$. glareolus with nematodes was relatively higher than with cestodes. The total infection of the vole with nematodes accounted for $65.3 \%$, 17.8. Trematodes of $C$. glareolus are represented by two species-P. maculosus and B. rodentini. The total infection of the rodent with trematodes was $1.9 \%, 0.1$. According to the PaliaKovnatsky index of dominance (D), the nematode S. petrusewiczii dominates (11.0) in the helminth fauna of $C$. glareolus from the National Park "Smolny". The subdominant species is the nematode H. mixtum (8.9). The remaining 12 parasites species in C. glareolus belong to the adominants.

Seven species of parasites were recorded in $M$. arvalis: 4 cestodes and 3 nematodes (Table 2). Six of them are host-specific parasites of the subfamily Arvicolinae (A. dentata, P. omphalodes, Catenotaenia sp. 1, Heligmosomum laevis (Dujardin, 1845), T. arvicolae, Syphacia nigeriana Baylis, 1928). One species-the metacestode V. mustelae, is a common parasite of myomorph rodents at this life stage. Microtus arvalis had no accidental and facultative parasites.

The general infection rate of $M$. arvalis reached $61.5 \%, 3.7$. Cestodes are represented by four species $(61.5 \%, 1.3)$, three of them parasitize at the mature stage $(61.5 \%, 1.3)$; one species, $V$. mustelae, larva does at the larval stage (Table 2). The nematode fauna of $M$. arvalis includes three species with a direct life cycle without involve intermediate hosts. The infection of the vole with nematodes accounted for $19.2 \%, 2.4$. In the helminth fauna of $M$. arvalis, the dominant is the cestode P. omphalodes (16.1); the subdominant species is the nematode $S$. nigeriana (6.6). The remaining five helminth species of the bank vole belong to adominants.

The fauna of $M$. agrestis helminths includes five species: 3 nematodes and 2 cestodes (Table 2). All of them are host-specific parasites of the subfamily Arvicolinae (P. omphalodes, Catenotaenia sp. 1, H. laevis, T. arvicolae and S. nigeriana). The general infestation of M. agrestis accounted for $54.5 \%, 6.2$. Cestodes are represented by two species parasitizing at the mature stage $(18.2 \%, 0.2)$. The nematode fauna of $M$. agrestis, similar to the one of $M$. arvalis, includes the same three species (Table 2). The general infestation of the vole with nematodes was $36.4 \%$, 6.0. In the helminth fauna of M. agrestis no dominant species have been identified. S. nigeriana (7.6) and H. laevis (3.2) are subdominants. The other three species of parasites are adominants. The helminth fauna in $M$. subterraneus include three helminth species: 2 cestodes and 1 nematode (Table 2), two of them (A. dentata and H. laevis), are host-specific parasites of subfamily Arvicolinae. The metacestode H. taeniaeformis s. 1 . is a common parasite of myomorph rodents at that life stage. The general invasion of M. subterraneus with helminth accounted for $33.3 \%$, 0.7. In M. subterraneus, we did not 
indicate the dominant species. All three species in helminthofauna of M. subterraneus belong to subdominants: H. taeniaeformis s. 1., larva-9.1, H. laevis-7.3 and A. dentata-1.2. Arvicola amphibius had one helminth species-the nematode H. laevis (Table 2). It is a host-generalist parasite of voles. Out of seven studied individuals of $A$. amphibius, only one was infected.

In $S$. flavicollis, we recorded seven parasite species: 1 trematode, 3 cestodes and 3 nematodes (Table 2). Five of them are host-specific parasites of rodents of the subfamily Murinae (the cestodes Spasskijela lobata (Baer, 1925), Hymenolepis apodemi Makarikov et Tkach, 2013, the nematodes Heligmosomoides polygyrus (Dujardin, 1845), Syphacia obvelata Rudolphi, 1802 and Syphacia stroma (Linstow, 1884)). The trematode Plagiorchis elegans (Rudolphi, 1802) is a facultative rodent parasite found in a wide range of vertebrates of different classes (birds, mammals and reptiles). The metacestode $H$. taeniaeformis s. 1. were revealed in many species of myomorph rodents that serve as intermediate hosts of the parasite.

The general infection of $S$. flavicollis with helminths reached $77.6 \%, 31.2$. Nematodes and cestodes in the helminth fauna of the rodent are equally represented-three species each (Table 2). Infection of S. flavicollis with nematodes reached 71.9\%, 30.9. All nematode species noted in the rodent had a direct life cycle, without intermediate hosts. Infection of $S$. flavicollis with cestodes accounted for $6.8 \%, 0.2$. Two species of cestodes parasitize at the mature stage $(5.7 \%, 0.2)$, one species-at the larval stage (Table 2). Only one species of trematodes-P. elegans, with low infection rates, was registered in S. flavicollis (Table 2). In the helminth fauna of $S$. flavicollis, the nematode Syphacia stroma was the dominant species (34.7). The subdominants included the nematodes H. polygyrus (7.2) and S. obvelata (2.1). The other four species of helminths are adominants.

The helminth fauna in S. uralensis includes 10 species: 3 trematodes, 3 cestodes and 5 nematodes (Table 2). Six of them belong to host-specific rodent parasites of the subfamily Murinae (the cestodes S. lobata, H. apodemi, the nematodes Trichuris muris (Schrank, 1788), H. polygyrus, S. obvelata and S. stroma). Three species (Corrigia vitta (Dujardin, 1845), M. muris and the metacestode $H$. taeniaeformis s. 1.) are host-generalist parasites of different rodent species. The trematode $P$. elegans is a facultative parasite of $S$. uralensis. General infection of the mouse with helminths accounted for $54.4 \%, 12.5$. Nematodes dominate in the helminth fauna of $S$. uralensis, which account for half of parasite species. Most of the nematode species of $S$. uralensis (4) have a direct life cycle, without involving intermediate hosts. One nematode species (M. muris) has a complex life cycle. The infection rate of the rodent with nematodes was relatively high and accounted for $47.6 \%, 11.9$. The infection rate of S. uralensis with cestodes reached $5.8 \%, 0.2$. Cestodes in $S$. uralensis are represented by two mature $(5.2 \%, 0.2)$ and one larval form (Table 2$)$. The trematode fauna of S. uralensis consist of only two species (Table 2), with infection $8.4 \%, 0.4$. The nematode S. obvelata is the dominant (14.2) in the helminth fauna of $S$. uralensis. The nematode H. polygyrus belongs to subdominants (5.7). The remaining eight parasite species of $S$. uralensis are adominants.

Twelve species of parasites were found in A. agrarius: 3 trematodes, 5 cestodes and 4 nematodes (Table 2). One of them, the nematode Syphacia agraria Sharpilo, 1973, is a hostspecific parasite of $A$. agrarius. Four species of helminths belong to host-generalist rodent parasites of the subfamily Murinae (cestodes S. lobata, H. apodemi, nematodes H. polygyrus and Heterakis spumosa Schneider, 1866). Three species (Brachylaima aequans (Looss 1899), M. muris, the metacestodes $V$. mustelae and H. taeniaeformis s. 1.) are common parasites of different rodent species. The trematodes P. elegans and Echinostoma miyagawai Ishii, 1932are facultative parasites of myomorph rodents. The random parasite of $A$. agrarius is the cestode $A$. dentata, a host-specific parasite of voles. The general infestation of $A$. agrarius with helminths reached $52.8 \%, 5.9$. Cestodes dominate in the helminth fauna of the mouse, the infestation is low and amounts to $4.6 \%, 0.07$. Three species of cestodes parasitize the rodent at the mature stage $(3.2 \%, 0.06)$ and two species-at the larval stage $(1.4 \%, 0.01)$. Nematodes in the helminth fauna of $A$. agrarius are represented by parasites with both direct (three species) and complex life cycle (one). The nematode infestation acconted for 
40.3\%, 5.0. Invasion of $A$. agrarius with trematodes, compared to other species of myomorph rodents of the National Park "Smolny", was relatively high and reach $17.6 \%, 0.9$. In the helminth fauna of $A$. agrarius, the dominant species is the nematode S. agraria (21.6). The subdominants include the trematode P. elegans (1.9) and nematode H. spumosa (1.3). The remaining nine parasite species are adominants.

Only two helminth species were found in S. betulina: the nematode M. muris and cestode Catenotaenia sp. 2 (Table 2). Of four studied S. betulina three individuals were infected with helminths.

On the territory of National Park "Smolny", the helminth fauna of S. uralensis and S. flavicollis (0.82), M. agrestis and M. arvalis (0.73) are the most similar in terms of the Morisita's overlap index (Table 3). The helminth fauna is less similar in A. agrarius and S. uralensis (0.52), A. agrarius иS. flavicollis (0.50), A. amphibius and M. subterraneus (0.50), $M$. arvalis and $M$. subterraneus (0.40), A. amphibius and $M$. agrestis (0.40), $M$. arvalis and C. glareolus (0.38). The least similarity of the helminth fauna was noted in C. glareolus and A. amphibius (0.10), S. flavicollis and C. glareolus (0.10), S. betulina and C. glareolus (0.13), S. betulina and A. agrarius (0.13), S. uralensis and M. subterraneus (0.15) (Table 3).

Table 3. Similarity of helminth fauna in myomorph rodents from the National park "Smolny" (Cm).

\begin{tabular}{|c|c|c|c|c|c|c|c|c|c|}
\hline Title 1 & Ms & $C g$ & Marv & $M a g r$ & Aam & $S f$ & $S u$ & $S b$ & Aagr \\
\hline M. subterraneus & 1 & 0.24 & 0.40 & 0.29 & 0.50 & 0.20 & 0.15 & 0.00 & 0.25 \\
\hline C. glareolus & 0.24 & 1 & 0.38 & 0.22 & 0.00 & 0.10 & 0.17 & 0.13 & 0.30 \\
\hline M. arvalis & 0.40 & 0.38 & 1 & 0.73 & 0.25 & 0.00 & 0.00 & 0.00 & 0.20 \\
\hline M. agrestis & 0.29 & 0.22 & 0.73 & 1 & 0.40 & 0.00 & 0.00 & 0.00 & 0.00 \\
\hline A. amphibius & 0.50 & 0.00 & 0.25 & 0.40 & 1 & 0.00 & 0.00 & 0.00 & 0.00 \\
\hline S. flavicollis & 0.20 & 0.10 & 0.00 & 0.00 & 0.00 & 1 & 0.82 & 0.00 & 0.50 \\
\hline S. uralensis & 0.15 & 0.17 & 0.00 & 0.00 & 0.00 & 0.82 & 1 & 0.17 & 0.52 \\
\hline S. betulina & 0.00 & 0.13 & 0.00 & 0.00 & 0.00 & 0.00 & 0.17 & 1 & 0.13 \\
\hline A. agrarius & 0.25 & 0.30 & 0.20 & 0.00 & 0.00 & 0.50 & 0.52 & 0.13 & 1 \\
\hline
\end{tabular}

Note: Ms-M. subterraneus, Cg-C. glareolus, Marv-M. arvalis, Magr-M. agrestis, Aam-A. amphibious, Sf-S. flavicollis, Su-S. uralensis, Sb-S. betulina, Aagr-A. agrarius.

The analysis of helminth diversity in myomorph rodents of National Park "Smolny" revealed that the helminth fauna is more diverse in $M$. arvalis (Shannon index $H^{\prime}=1.101$ ), M. subterraneus (1.036) and S. uralensis (1.018). The helminth fauna is less diverse in S. flavicollis (0.896) and A. agrarius (0.844). Low Shannon index values of the helminth fauna were recorded in $M$. agrestis $\left(\mathrm{H}^{\prime}=0.589\right)$ and $C$. glareolus $(0.482)$. The differences between the Shannon index values are significant in most cases at $p<0.001$; in M. arvalis and $M$. agrestis at $p<0.01$; in S. flavicollis and M. arvalis, S. flavicollis and $M$. agrestis at $p<0.05$. In the case of $M$. arvalis and M. subterraneus, C. glareolus and M. agrestis, $S$. flavicollis and $A$. agrarius, $M$. arvalis and $S$. uralensis, $S$. uralensis and $M$. subterraneus, the differences of the Shannon index values are not significant $(p>0.05)$.

Nematodes that dominate in the helminth fauna of myomorph rodents from the National Park "Smolny" belong to five families (Table 2). The most represented families are Oxyuridae (5 species) and Heligmosomidae (4). The Trichuridae family includes two species. The smallest number of species is in the families Spirocercidae and Heterakidae (one each).

Cestodes are also represented by five families, and parasites of the families Catenotaeniidae (4 species) and Taeniidae (3) dominate. The family Anoplocephalidae includes two cestode species. The families Dilepididae and Hymenolepididae include 1 species each (Table 2).

Trematodes (6 species) are less represented in the helminth fauna of myomorph rodents from the National Park "Smolny" and belong to four families (Table 2). The families Plagiorchiidae and Dicrocoeliidae include two trematode species; the families Brachylaimidae and Echinostomatidae include one species each. 
The nematode $S$. stroma is widely distributed in myomorph rodents and registered in 13 of the 15 localities (Table 2 and Figure 1). The nematodes H. polygyrus, H. mixtum and $S$. obvelata were recorded in 12 studied sites. The cestode P. omphalodes was found in micromammals in nine localities. The cestodes C. henttoneni, S. lobata and the nematode S. petrusewiczii were found each in 7 studied places. The nematode S. agraria was registered in 6 stations. The trematode P. elegans, the nematode $H$. spumosa and the metacestode $H$. taeniaeformis s. 1 . were noted in five localities. The metacestode $V$. mustelae was found in rodents in four localities. The cestodes $H$. apodemi and the nematodes $H$. glareoli, H. laevis, T. arvicolae, T. muris were each registered in three studied places. The remaining 13 parasite species were observed only in one or two research sites (Table 2 and Figure 1).

There were no common helminths in the all studied rodent species. Five rodent hosts had one common metacestode $H$. taeniaeformis s. 1 . (Table 2). Four hosts had the cestode $A$. dentata and nematodes $H$. laevis and $M$. muris. Three rodent hosts are noted for six helminth species (P. omphalodes, H. apodemi, V. mustelae, larva, P. elegans, T. arvicolae, H. polygyrus). The nematodes S. nigeriana, S. obvelata, S. stroma and the cestode Catenotaenia sp. 1, were recorded in two host species. The remaining 16 parasite species each had one host (Table 2).

Most of the parasites (15 species) identified in rodents from the National Park "Smolny" belong to the Palearctic faunistic complex. It includes the cestodes P. omphalodes, S. lobata, $D$. undula, the trematodes $B$. aequans, B. rodentini, C. vitta, E. miyagawai, the nematodes T. arvicolae, T. muris, $H$. glareoli, H. laevis, $H$. polygyrus, $H$. mixtum, S. agraria and S. stroma. Six parasite species are cosmopolitans: the cestodes $H$. apodemi, H. taeniaeformis s.l., the trematode $P$. maculosus, the nematodes $S$. obvelata, $H$. spumosa and M. muris. Five helminths have a Holarctic distribution: the cestodes $A$. dentata, V. mustela, the trematode P. elegans, the nematodes $S$. nigeriana and $S$. petrusewiczi. The distribution of four helminth species (Catenotaenia spp. and T. martis) is limited to Europe (Table 2).

Two out of 30 species of helminths (the metacestode H. taeniaeformis s. 1 . and the nematode S. obvelata) found in the myomorph rodents from the National Park "Smolny" have medical and veterinary significance as potential pathogens of dangerous helminthiasis.

\subsection{Comparative Analysis of the Helminth Fauna in Rodents}

We have carried out a comparative analysis of the helminth fauna in myomorph rodents from different regions of European Russia. Figure 2 shows the dendrogram of the similarity of the helminth fauna in myomorph rodents. The cophenetic correlation coefficient is 0.811 , which confirms the validity of the cluster. During clustering, all the considered species of micromammals were divided into 10 groups that include species with the most similar helminth fauna.

The first group is formed by the helminth fauna of M. minutus from the Central Chernozem Nature Biosphere Reserve (Kursk region) and Samarskaya Luka (Samara region). It differs as much as possible from the helminth fauna in other studied micromammal species on the territory of European Russia (Figure 2).

The second group is formed by the helminth fauna of C. glareolus from the Central Chernozem Reserve, Belogorye State Nature Reserve (Belgorod region) and Mordovia State Nature Reserve (Republic of Mordovia).

The third group is divided into two subgroups, represented by the parasite fauna of voles (Figure 2). The first subgroup is divided into the helminth fauna of Microtus voles from the Central Chernozem Reserve, Samarskaya Luka, Voronezh State Nature Reserve (Voronezh region) and the helminth community of C. glareolus from the Voronezh Nature Reserve, Samarskaya Luka, National Park "Smolny" and Republic of Karelia. The helminth fauna in M. oeconomus and M. agrestis from the Republic of Karelia is added to the helminth community of $C$. glareolus. The second subgroup is formed by the helminth fauna of ecologically close vole species from the Voronezh Nature Reserve and the species A. amphibius from the Republic of Karelia (Figure 2). In the group, helminth fauna in C. glareolus from the National Park "Smolny" has the greatest similarity with M. oeconomus 
(0.61) and C. glareolus from the Republic of Karelia (0.58 each) and C. glareolus from the Samarskaya Luka (0.57).

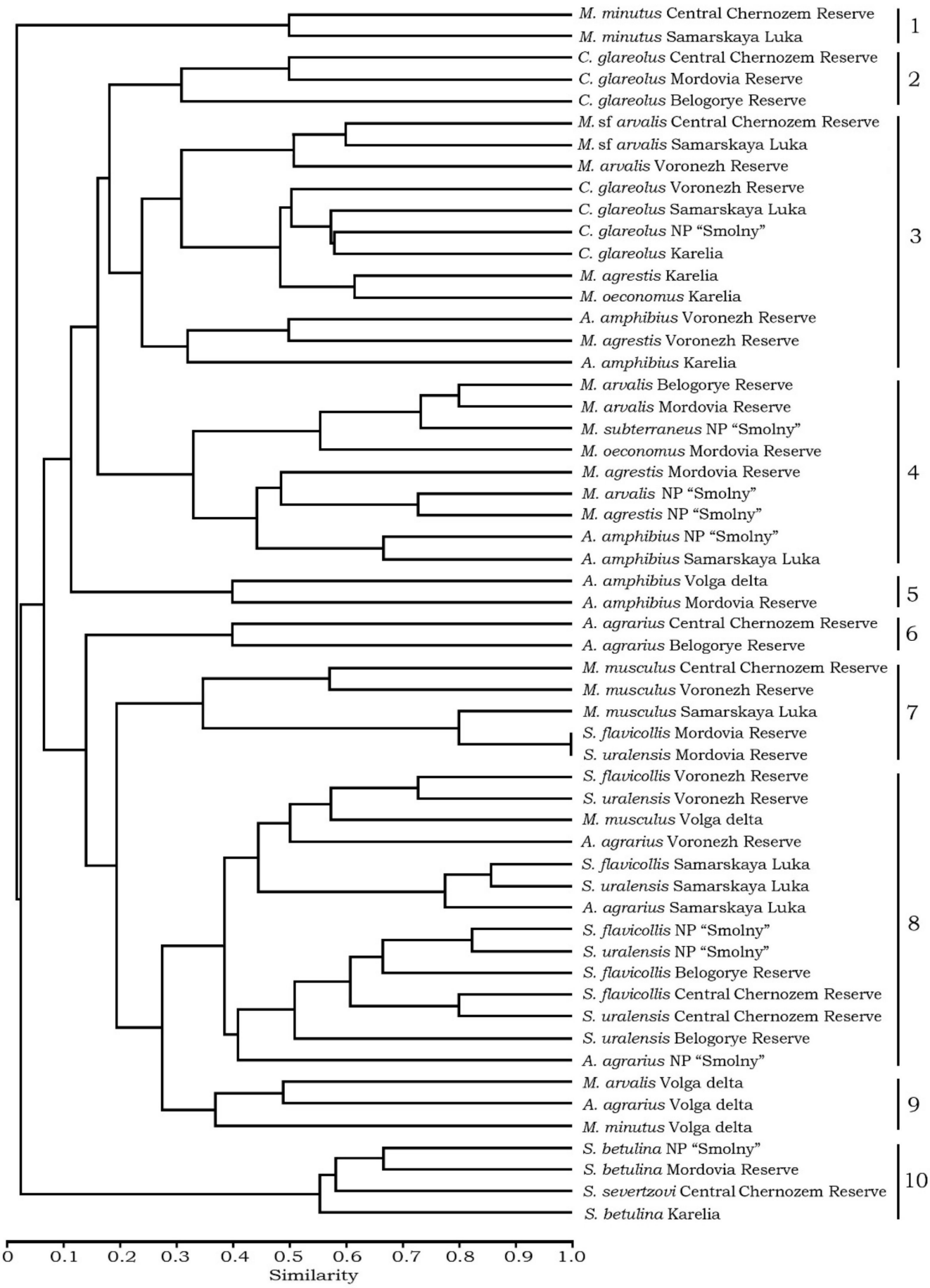

Figure 2. Similarity dendrogram of the helminth fauna in myomorph rodents from different regions of European Russia, obtained by the Morisita index (UPGMA). Correlation Coefficient: $r=0.811$.

The fourth group is divided into two subgroups. The first subgroup is formed by the helminth fauna in $M$. arvalis from the Belogorye Nature Reserve and Mordovia Nature Reserve and the parasite fauna in M. subterraneus from the National Park "Smolny". The helminth fauna in $M$. oeconomus from the Mordovia Nature Reserve is adjacent to this subgroup. The second subgroup includes the helminth fauna in $M$. agrestis from the Mordovia Nature Reserve, M. arvalis and M. agrestis from the National Park "Smolny". 
The parasites in A. amphibius from the National Park "Smolny" and Samarskaya Luka are adjacent to this subgroup (Figure 2). The helminth fauna in M. subterraneus from the National Park "Smolny" in the subgroup has a high degree of similarity with $M$. arvalis from the Mordovia Nature Reserve (0.80) and Belogorye Nature Reserve (0.67), and in the group with $A$. amphibius from the Samarskaya Luka (0.40). The parasite fauna in $M$. arvalis from the National Park "Smolny" in the subgroup has a high degree of similarity with M. agrestis from the Mordovia Nature Reserve (0.40), and in the group-with M. arvalis from the Belogorye Nature Reserve (0.60). The helminth fauna in $M$. agrestis from the National Park "Smolny" had the greatest similarity with A. amphibius from the Samarskaya Luka (0.67) and $M$. agrestis from the Mordovia Nature Reserve (0.57) in the group.

The fifth and sixth groups have one species. The fifth one is formed by the helminth fauna in A. amphibius from the Volga delta (Astrakhan region) and the Mordovia Nature Reserve, and the sixth one is formed by the helminth community in A. agrarius from neighboring the Central Chernozem Reserve and Belogorye Nature Reserve.

The seventh group is formed by two subgroups. The first subgroup of the helminth fauna in M. musculus from the Central Chernozem Reserve and Voronezh Nature Reserve. The second subgroup is represented by the parasite fauna of forest mice from the Mordovia Nature Reserve and the adjacent M. musculus from the Samarskaya Luka (Figure 2).

The eighth group is also divided into two subgroups. The first subgroup is formed by the helminth fauna of mice from the Voronezh Nature Reserve and M. musculus from the Volga delta. The second subgroup is formed by the parasite fauna of mice from the National Park "Smolny", Central Chernozem Reserve and Belogorye Nature Reserve (Figure 2). The helminth fauna in A. agrarius from the National Park "Smolny" has the greatest similarity with S. flavicollis and S. uralensis from the Central Chernozem Reserve (per 0.38) in the subgroup and with A. agrarius from the Samarskaya Luka (0.41) in the group. The fauna of parasites in S. uralensis from the National Park "Smolny" has the greatest similarity with the helminth fauna in S. flavicollis from the Belogorye Nature Reserve (0.67) in the subgroup, and with S. uralensis from the Samarskaya Luka and Voronezh Nature Reserve (0.59 each) in the group. In the subgroup, the helminth fauna in S. flavicollis from the National Park "Smolny" is most similar to the parasite fauna in S. flavicollis (0.67) and S. uralensis (0.60) from the Belogorye Nature Reserve, S. uralensis (0.63) and S. flavicollis (0.62) from the Central Chernozem Reserve. And in the group, the helminth fauna in S. flavicollis from the National Park "Smolny" has a high similarity with S. uralensis from the Voronezh Nature Reserve (0.58).

The ninth group is three-species and formed by the helminth fauna of rodents from the Volga delta. The tenth group is formed by the parasite fauna in birch mice from the National Park "Smolny', Mordovia Nature Reserve, Central Chernozem Reserve and Karelia. The helminth fauna in S. betulina from neighboring the National Park "Smolny" and Mordovia Nature Reserve (0.67) shows the greatest similarity in the group (Figure 2).

\section{Discussion}

The analysis of the helminth fauna in myomorph rodents from the National Park "Smolny" showed that the species composition of parasites is qualitatively rich in C. glareolus (14 species), A. agrarius (12) and S. uralensis (10). It is less diverse in S. flavicollis, $M$. arvalis (7 species each) and M. agrestis (5). The helminth fauna in M. subterraneus (3), S. betulina (2) and A. amphibius (1) is very poor. Parasites were not detected in the studied single specimens of M. musculus and M. minutus, which is due to the small number of studied rodents.

The diversity of the helminth fauna in individual species of myomorph rodents is determined by the size of the ecological niche that the animal occupies in the biocenosis. The most diverse and rich helminth fauna is possessed by the most abundant and eurybiont rodent species such as $C$. glareolus, A. agrarius, S. uralensis and S. flavicollis.

For the majority of helminths (26 species), rodents serve as obligate hosts. They are facultative hosts for trematodes P. elegans, P. maculosus, E. miyagawai and cestode D. undula. 
Obligate hosts of P. elegans, P. maculosus, and D. undula are birds of different orders, mainly Passeriformes; and waterfowl is for E. miyagawai $[45,46]$.

The finding of cestode larvae in myomorph rodents indicates the important role of these micromammals in the circulation of animal parasites at higher trophic levels. Adult forms of $H$. taeniaeformis s. 1., T. martis and V. mustelae parasitize predatory mammals of the families Mustelidae and Canidae. On the other hand, the records of metacestodes in small rodents indicates a wide distribution of the final hosts of these parasites in biocenoses of the National Park. The invasion of rodents by these cestode species occurs by oral penetration of helminth eggs into the host along with food [45,47]. According to recent molecular genetic studies, the cestode of $H$. taeniaformis s. 1 . is a species complex and contains at least two or three cryptic species forming three clearly differentiated clades A (H. taeniaformis s. str.), B (Hydatigera kamiyai Iwaki 2016) and C (Hydatigera sp.) [61,62].

Invasion of $C$. glareolus with the cestode D. undula probably occurred while eating the intermediate hosts of the cestode which are oligochaete worms [45]. In our opinion, the findings of immature cestodes D. undula in the small intestine of rodents are cases of transit parasitism.

Invasion of rodents with the cestodes A. dentata, P. omphalodes, S. lobata and Catenotaenia spp. is carried out by accidental ingestion along with plant food (or by digging burrows) of intermediate hosts of these parasites which are oribatid and tyroglyphid mites and Onchiurus springtails $[46,48]$. Molecular genetic studies have shown that the cestode $A$. dentata is a species complex and includes at least five species common in the Holarctic [63]. The cestode P. omphalodes, which is widely distributed among the voles of Eurasia, also includes several species $[64,65]$. Recent studies have shown that Catenotaenia cestodes possess a high degree of specificity. Catenotaenia cricetorum Kirshenblat, 1949, previously observed in a large number of rodent species from the European fauna [51], is a combined species. New species were described for mice (Catenotaenia apodemi Haukisalmi, Hardman et Henttonen, 2010), for the Grey dwarf hamster Cricetulus barabensis (Pallas, 1773) (Catenotaenia cricetuli Haukisalmi, Hardman et Henttonen, 2010) and for the Social vole Microtus socialis (Pallas, 1773) (Catenotaenia microti Haukisalmi, Hardman et Henttonen, 2010). Catenotaenia henttoneni is host-specific parasite for Clethrionomys voles [51].

The development of cestodes of the genus Hymenolepis Weinland, 1858 proceeds with the involvement of millipedes and insects of the orders Coleoptera, Lepidoptera and Orthoptera $[46,48]$. Rodents become infected with H. apodemi by eating insects and millipedes. Recent studies have revealed that the genus Hymenolepis includes several complex species, which may include a number of yet undescribed hymenolepidids. Thus, the rat parasite Hymenolepis diminuta (Rudolphi, 1819), described from R. norvegicus, was indicated for many rodent species of different families, including Apodemus and Sylvaemus mice [46]. Recently it has been established that $H$. diminuta is a complex of cryptic species [66]. $H y$ menolepis hibernia Montgomery, Montgomery et Dunn, 1987 and H. apodemi parasitise mice of Eurasia $[49,67]$.

Myomorph rodents become infected with trematodes while eating invertebrates, which serve as the second intermediate hosts of these parasites. When visiting near-water stations, rodents eat aquatic and near-water insects which are the second intermediate hosts of Plagiorchis trematodes. As the result, they become infected with P. elegans and P. maculosus $[46,48]$. Also, near waterbodies, micromammals become infected with E. miyagawai, while eating freshwater gastropods that are the second intermediate hosts of the parasite. It has been experimentally established that they may be the limneids Lymnaea stagnalis (Linnaeus, 1758) and Lymnaea truncatula (Muller, 1774) [68,69]. Or rodents eat tadpoles of Rana frogs which are also indicated as the second intermediate hosts of this trematode [46,48]. Freshwater gastropods Planorbis planorbis (Linnaeus, 1758), Anisus vortex (Linnaeus, 1758), Radix peregra (Muller, 1774), Galba corvus (Gmelin, 1791) and Gyraulus chinensis (Dunker, 1848) serve as the first intermediate hosts of E. miyagawai [70], they probably could also act as second intermediate hosts. 
Infection of rodents with the trematode $C$. vitta occurs when eating woodlice of the genera Porcellio Latreille, 1804 and Philosophia Latreille, 1804 [71]. Myomorph rodents become infected with the $B$. aequans trematode by eating terrestrial gastropods of the genus Macrochlamys Benson, 1832 [48].

The life cycle of B. rodentini has not been studied, but, probably, like in other dicroceliid species, the second intermediate hosts of the trematodes are insects [46]. While eating them, rodents become infected with this parasite.

The absence of trematodes in the helminth fauna of M. arvalis, M. agrestis and M. subterraneus indicate the avoidance of near-water habitats by these rodents and a small quantity of near-water plants in the rodent diet. Invertebrate feeding is not typical for Microtus voles. The absence of trematodes in the helminth fauna of the water vole and birch mouse is mainly due to the small number of studied rodents of these species.

Infection of rodents with helminths that have a direct life cycle (nematodes) occurs as a result of close contact with the soil. When feeding on the green parts of plants, active burrowing, rodents accidentally swallow both eggs of nematodes (H. spumosa, genera Trichuris and Syphacia) and invasive larvae of parasites (genera Heligmosomum and Heligmosomoides) [47,71]. Recent studies of the morphological and genetic variability of Trichuris spp. have revealed that $T$. arvicolae parasitizes in rodents of the Arvicolinae subfamily, and T. muris parasitizes in mice $[55,72,73]$.

The rodents become infected with the nematode M. muris, which has an indirect life cycle, by eating insects-intermediate hosts of the parasite (dung beetles of the genus Geotrupes Latreille, 1797, locusts, grasshoppers, crickets, earwigs and cockroaches) or, which is unlikely, paratenic hosts-amphibians $[47,71,74]$.

The metacestode $H$. taeniaeformis s. 1., which has veterinary significance, can cause hydatigerosis of wild and domestic carnivores $[27,75,76]$. The nematode $S$. obvelata is potentially dangerous to man and can cause human syphaciosis [27,76]. We have not found in small rodents of the National Park "Smolny" a dangerous parasite the metacestode Echinococcus multilocularis Leuckart, 1863, which causes echinococcosis of humans and animals [75,76]. Despite the widespread distribution of E. multilocularis in the northern and central regions of Eurasia in the final hosts-carnivores [48,75], single findings of the parasite in M. arvalis and A. agrarius from the Samarskaya Luka (Middle Volga region) were recorded in rodents of European Russia [27,28,77].

A comparison of the parasite fauna in the studied rodent species from the National Park "Smolny" showed that the helminth fauna of micromammals within the subfamilies Murinae and Arvicolinae is most similar in terms of the Morisita's overlap index (Table 3). The revealed similarity of the helminth fauna of different rodent species is mainly due to the diet of herbaceous vegetation (voles), seeds of plants and fruits (mice), as well as the phylogenetic relationship of animals.

The analysis of the helminth species diversity in myomorph rodents showed that the helminth fauna of $M$. arvalis, $M$. subterraneus and S. uralensis is more diverse, despite the fact that $A$. agrarius (12 species) and C. glareolus (14) have a greater number of helminth species. The Shannon index values are lower in these rodent species due to the high abundance and dominance of Syphacia nematodes in their helminth fauna (Table 2). This is also due to the presence of a larger number of single and random parasite species in A. agrarius and C. glareolus. As a result, Shannon index showed that the helminth fauna in M. arvalis (7 species), M. subterraneus (3) and S. uralensis (10) are more diverse than in A. agrarius and C. glareolus.

The helminth diversity in myomorph rodents in a particular locality is associated with different natural conditions of their habitats. The fauna of animal parasites is influenced by many factors: the diversity of the fauna of vertebrates and invertebrates in the biocenosis, which can serve as intermediate and final hosts of helminths, microclimatic conditions of animal habitats, host population density, diet features, etc. [2,78-85].

Despite the relatively high helminth diversity observed in the myomorph rodents from the National Park "Smolny", it still does not reach its maximum, since more than 80 species of 
parasitic worms are known for small wild rodents in European Russia [9,27-34,45,77,86-88]. Thus, we have registered 39 helminth species in the myomorph rodents from the Samarskaya Luka, located $300 \mathrm{~km}$ south-east [27,28,34,77]. In Karelia, 35 species of helminths were identified in small rodents [45,87]. In the Voronezh State Nature Reserve, 53 species of parasites were observed in small rodents [29,31]. Fifty-one species of helminths are known for myomorph rodents from the Volga delta $[30,86]$. In the Central Chernozem Reserve, 32 species of helminths were observed in myomorph rodents [32]. For small rodents of the Belogorye State Nature Reserve, 20 species of parasites were indicated [9]. Fifteen species of parasitic worms were found in myomorph rodents from the Mordovia State Nature Reserve [33].

There was a high degree of similarity, according to a comparative analysis of the helminth fauna of myomorph rodents from the National Park "Smolny" with the parasite fauna of small rodents from other territories of Russia. The degree of similarity of helminth fauna in rodents is determined by the presence of a larger or smaller number of hostspecific parasite species that are found throughout the range of the rodent host. Most of the recorded helminth species in micromammals ( 26 out of 30 registered) are obligate parasites of rodents that are widely distributed in Russia and Europe. This is due to the wide distribution of both final rodent hosts and intermediate hosts of their helminths.

\section{Conclusions}

Thus, the helminth fauna of 11 species of myomorph rodents from the National Park "Smolny" is represented by 30 species: 6 trematodes, 11 cestodes and 13 nematodes. No parasites were found in M. musculus and M. minutus.

The trematode P. maculosus was found in C. glareolus in the fauna of Russia for the first time. C. glareolus is indicated as a new host for the trematode. M. arvalis is noted as a new host for the metacestode $V$. mustelae.

The richness of the helminth fauna of different species of myomorph rodents is determined by the size of the ecological niche of micromammals that they occupy in the biocenosis. Among the small rodents from the National Park "Smolny", the most diverse helminth fauna is in numerous and widespread species: in rodents of the subfamily Arvicolinae-C. glareolus; in rodents of the subfamily Murinae-S. uralensis and A. agrarius. Species with low numbers and limited trophic and/or spatial niches are characterized by a poor helminth fauna (M. subterraneus, S. betulina and A. amphibius).

A comparative analysis of the helminth fauna in myomorph rodents showed that the parasite composition in M. subterraneus from the National Park "Smolny" reaches the maximum similarity with other regions of European Russia. High similarity with other regions of Russia was noted for the helminth fauna in S. flavicollis, S. uralensis, A. amphibious, S. betulina and M. agrestis. The fauna of the helminths in A. agrarius, C. glareolus and $M$. arvalis is less similar to other studied areas.

Two out of 30 helminth species found in myomorph rodents have medical and veterinary significance as potential pathogens of dangerous helminthiasis. These include the cestode $H$. taeniaeformis s. 1 . and the nematode $S$. obvelata.

Author Contributions: Conceptualization, A.R. and N.K.; methodology, A.K. and N.K.; formal analysis, A.K. and N.K.; investigation, A.K. and N.K.; writing-original draft preparation, A.K., N.K. and A.R.; writing-review and editing, A.K. and A.R.; project administration, A.R.; funding acquisition, A.R. All authors have read and agreed to the published version of the manuscript.

Funding: This research received no external funding.

Institutional Review Board Statement: Not applicable.

Informed Consent Statement: Not applicable.

Data Availability Statement: The data presented in this study are available on request from the corresponding author. 


\begin{abstract}
Acknowledgments: The authors are deeply grateful to the direction and staff of the National Park "Smolny" for their help and support related to the collection of parasitological material. The work was carried out on the theme of research of the Institute of Ecology of the Volga River Basin-a branch of the Samara Federal Research Center of the Russian Academy of Sciences "Ecological patterns of sustainable functioning of ecosystems and the potential resources of the Volga basin" AAAA-A17-117112040039-7.
\end{abstract}

Conflicts of Interest: The authors declare no conflict of interest.

\title{
References
}

1. Price, P.W. Evolutionary Biology of Parasites; Princeton University Press: Princeton, NJ, USA, 1980; pp. 3-237.

2. Poulin, R.; Morand, S. Parasite Biodiversity; Smithsonian Institution Press: Washington, DC, USA, 2004 ; pp. 3-216.

3. Horwitz, P.; Wilcox, B. Parasites, ecosystems and sustainability: An ecological and complex systems perspective. Int. J. Parasitol. 2005, 35, 725-732. [CrossRef]

4. Chikhlyaev, I.V.; Ruchin, A.B.; Fayzulin, A.I. The helminth fauna study of European common toad in the Volga basin. Nat. Environ. Pollut. Technol. 2016, 15, 1103-1109.

5. Saidi, A.; Mimouni, R.; Hamadi, F.; Oubrou, W. Cross-sectional study of Eimeria spp. infection in three antelope species (Addax nasomaculatus, Gazella dorcas and Oryx dammah) maintained in the Souss-Massa National Park (Morocco). Nat. Conserv. Res. 2020, 5,77-82. [CrossRef]

6. Seryodkin, I.V.; Odoyevskaya, I.M.; Konyaev, S.V.; Spiridonov, S.E. Trichinella infection of wild carnivorans in Primorsky Krai, Russian Far East. Nat. Conserv. Res. 2020, 5, 31-40. [CrossRef]

7. Chikhlyaev, I.V.; Ruchin, A.B. An overview of the helminths of moor frog Rana arvalis Nilsson, 1842 (Amphibia: Anura) in the Volga basin. Diversity 2021, 13, 61. [CrossRef]

8. Preisser, W. Latitudinal gradients of parasite richness: A review and new insights from helminths of cricetid rodents. Ecography 2019, 42, 1315-1330. [CrossRef]

9. Kononova, M.I.; Prisniy, Y.A. Helminthes of mouse-like rodents in the Belogorye State Nature reserve (Russia). Nat. Conserv. Res. 2020, 5, 11-18. [CrossRef]

10. Poulin, R.; Presswell, B.; Jorge, F. The state of fish parasite discovery and taxonomy: A critical assessment and a look forward. Int. J. Parasitol. 2020, 50, 733-742. [CrossRef]

11. Pringle, R. Upgrading protected areas to conserve wild biodiversity. Nature 2017, 546, 91-99. [CrossRef]

12. Ghosh-Harihar, M.; An, R.; Athreya, R.; Borthakur, U.; Chanchani, P.; Chetry, D.; Datta, A.; Harihar, A.; Karanth, K.K.; Mariyam, D.; et al. Protected areas and biodiversity conservation in India. Biol. Conserv. 2019, 237, 114-124. [CrossRef]

13. Minin, A.A.; Ananin, A.A.; Buyvolov, Y.A.; Larin, E.G.; Lebedev, P.A.; Polikarpova, N.V.; Prokosheva, I.V.; Rudenko, M.I.; Sapelnikova, I.I.; Fedotova, V.G.; et al. Recommendations to unify phenological observations in Russia. Nat. Conserv. Res. 2020, 5, 89-110. [CrossRef]

14. Mohd-Azlan, J.; Lok, L.; Maiwald, M.J.; Fazlin, S.; Shen, T.D.; Kaicheen, S.S.; Dagang, P. The distribution of medium to large mammals in Samunsam Wildlife Sanctuary, Sarawak in relation to the newly constructed Pan-Borneo Highway. Nat. Conserv. Res. 2020, 5, 43-54. [CrossRef]

15. Simonov, S.A.; Matantseva, M.V. Analysis of the current status of avifauna in Kostomuksha State Nature Reserve and Kalevala National Park (North-West Russia), taking into account influence from adjacent areas. Nat. Conserv. Res. 2020, 5, 51-65. [CrossRef]

16. Maron, M.; Simmonds, J.S.; Watson, J.E.M. Bold nature retention targets are essential for the global environment agenda. Nat. Ecol. Evol. 2018, 2, 1194-1195. [CrossRef]

17. Kestemont, B. The bottom-up assessment of threatened species. Nat. Conserv. Res. 2019, 4, 93-106. [CrossRef]

18. Kopoteva, T.A.; Kuptsova, V.A. Effects of pyrogenic factor on wetlands of Petrovskaya Pad' (Jewish Autonomous Region, Russia). Nat. Conserv. Res. 2019, 4, 35-44. [CrossRef]

19. Lebedinskii, A.A.; Noskova, O.S.; Dmitriev, A.I. Post-fire recovery of terrestrial vertebrates in the Kerzhensky State Nature Biosphere Reserve (Central Volga Region, Russia). Nat. Conserv. Res. 2019, 4, 45-56. [CrossRef]

20. Ruchin, A.B.; Khapugin, A.A. Red data book invertebrates in a protected area of European Russia. Acta Zool. Acad. Sci. Hung. 2019, 65, 349-370. [CrossRef]

21. Maxwell, S.L.; Cazalis, V.; Dudley, N.; Hoffmann, M.; Rodrigues, A.S.L.; Stolton, S.; Visconti, P.; Woodley, S.; Kingston, N.; Lewis, E.; et al. Area-based conservation in the twenty-first century. Nature 2020, 586, 217-227. [CrossRef]

22. Rutovskaya, M.V.; Aleksandrov, A.N.; Podshivalina, V.N.; Soboleva, A.S.; Glushenkov, O.V. Habitat conditions of Desmana moschata (Talpidae, Eulipotyphla, Mammalia) in the buffer zone of the Prisurskiy State Nature Reserve (Russia). Nat. Conserv. Res. 2020, 5, 36-46. [CrossRef]

23. Lyubimov, A.; Kryuchkov, A.; Eglit, A.; Ivanova, D.; Khumalo, N. Improvement of the strictly protected areas nets in Russian Federation. Sam. Luka Probl. Region. Glob. Ecol. 2018, 27, 17-20. [CrossRef]

24. Negrobov, O.P.; Maslova, O.O.; Selivanova, O.V. Fauna of the family Dolichopodidae (Diptera) of the Astrakhan State Nature Biosphere Reserve (Russia). Nat. Conserv. Res. 2018, 3 (Suppl. 2), 91-96. [CrossRef] 
25. Kirillova, N.Y.; Kirillov, A.A.; Shchenkov, S.V.; Chikhlyaev, I.V. Oswaldocruzia filiformis sensu lato (Nematoda: Molineidae) from amphibians and reptiles in European Russia: Morphological and molecular data. Nat. Conserv. Res. 2020, 5 (Suppl. 2), 41-56. [CrossRef]

26. Bondarenko, A.S.; Zamotajlov, A.S.; Belyi, A.I.; Khomitskiy, E.E. Fauna and ecological characteristics of ground beetles (Coleoptera, Carabidae) of the Nature Sanctuaries "Prichernomorskiy" and "Tuapsinskiy" (Russia). Nat. Conserv. Res. 2020, 5, 66-85. [CrossRef]

27. Kirillova, N.Y. Helminths in Small Mammals from the Samarskaya Luka. In Fauna and Ecology; Lambert Academic Publishing: Saarbrucken, Germany, 2011; pp. 3-251.

28. Kirillova, N.Y.; Kirillov, A.A. Overview of helminths in small mammals in the Zhiguli State Reserve. Nat. Conserv. Res. 2017, 2, 24-37. [CrossRef]

29. Romashov, B.V. Helminths of myomorph rodents of the Usmanskiy forest. Proc. Voronezh Reserve 1997, 23, $186-206$.

30. Ivanov, V.M.; Kalmykov, A.P.; Fedorovich, V.V.; Semenova, N.N.; Parshina, O.Y. Structural changes in helminthofauna of rodents resulted from introduction and settling of animals in the Volga delta. Arid Ecosyst. 2011, 17, 76-82.

31. Romashova, N.B. Recent fauna and ecology of helminths of myomorph rodents of the Usmanskiy forest. Proc. Voronezh Reserve 2012, 42, 184-194.

32. Vlasov, E.F.; Malysheva, N.S.; Krivopalov, A.V. Helminth fauna of myomorh rodents (Rodentia, Myomorha) in the Central Chernozem State Nature Reserve. Rus. Parasitol. J. 2015, 4, 24-33. [CrossRef]

33. Ruchin, A.B.; Kirillov, A.A.; Chikhlyaev, I.V.; Kirillova, N.Y. Parasitic Worms of Land Vertebrates of the Mordovia Nature Reserve. In Flora and Fauna of Reserves; Committee of RAS for the Conservation of Biological Diversity: Moscow, Russia, 2016; Volume 124, pp. 3-72.

34. Kirillov, A.A.; Kirillova, N.Y.; Krasnobaev, Y.P.; Vekhnik, V.P. Parasitic worms of small mammals of Zhiguli State Reserve. In Flora and Fauna of Reserves; Committee of RAS for the Conservation of Biological Diversity: Moscow, Russia, 2017; Volume 128, pp. 3-77.

35. Meerburg, B.G.; Singleton, G.R.; Kijlstra, A. Rodent-borne diseases and their risks for public health. Crit. Rev. Microbiol. 2009, 35, 221-270. [CrossRef]

36. Bordes, F.; Blasdell, K.; Morand, S. Transmission ecology of rodent-borne diseases: New frontiers. Integr. Zool. 2015, 10, 424-435 [CrossRef] [PubMed]

37. Krucken, J.; Blumke, J.; Maaz, D.; Demeler, J.; Ramunke, S.; Antolova, D.; Schaper, R.; von Samson-Himmelstjerna, G. Small rodents as paratenic or intermediate hosts of carnivore parasites in Berlin, Germany. PLoS ONE 2017, 12, e0172829. [CrossRef] [PubMed]

38. Levykh, A.Y.; Panin, V.V. Species composition and community structure of small mammals in Parapolsky Dol (Koryak State Nature Reserve, Kamchatka). Nat. Conserv. Res. 2019, 4, 1-12. [CrossRef]

39. Ahissa, L.; Akpatou, B.K.; Bohoussou, H.K.; Kadjo, B.; Kone, I. Species composition and community structure of terrestrial small mammals in Tanoé-Ehy Swamp Forest (South-East Ivory Coast): Implication for conservation. Nat. Conserv. Res. 2020, 5, 53-63. [CrossRef]

40. Kirillova, N.Y.; Kirillov, A.A.; Ruchin, A.B. First record of helminths of the European pine vole, Microtus subterraneus (Rodentia, Cricetidae) in Russia with overview on the rodent's range. Rus. J. Theriol. 2021. 20, 19-24. [CrossRef]

41. Grishutkin, G.F.; Lapshin, A.S.; Spiridonov, S.N.; Artaev, O.N.; Ruchin, A.B.; Kuznetsov, V.A.; Andreychev, A.V. Vertebrate animals of National Park "Smolny". In Flora and Fauna of Reserves; Issue 124; Committee of RAS for the Reserve of Biological Diversity: Moscow, Russia, 2013; pp. 3-56.

42. Kirillova, N.Y.; Krystufek, B.; Kirillov, A.A.; Ruchin, A.B.; Grishutkin, G.F. The first record of Microtus subterraneus (de SelysLongchamps, 1836) (Rodentia, Cricetidae) for Mordovia, Russia. Acta Biol. Sibir. 2019, 5, 145-149. [CrossRef]

43. Directive 2010/63/EU of the European Parliament and of the Council of 22 September 2010 on the protection of animals used for scientific purposes. OJEU 2010, L276, 33-79.

44. Ivashkin, V.M.; Kontrimavichus, V.L.; Nasarova, N.S. Methods of the Collection and Studies of Helminths of Land Mammals; Nauka: Moscow, Russia, 1971; pp. 3-123.

45. Anikanova, V.S.; Bugmyrin, S.V.; Ieshko, E.P. Methods of the Collection and Studies of Helminths of Small Mammals; Karelian Scientific Center of RAS: Petrozavodsk, Russia, 2007; pp. 3-145.

46. Ryzhikov, K.M.; Gvozdev, E.V.; Tokobaev, M.M.; Shaldybin, L.C.; Matsaberidze, G.V.; Merkusheva, I.V.; Nadtochiy, E.V.; Khokhlova, I.G.; Sharpilo, L.D. Keys to the helminths of rodents in the USSR fauna. In Cestodes and Trematodes; Nauka: Moscow, Russia, 1978; pp. 3-232.

47. Ryzhikov, K.M.; Gvozdev, E.V.; Tokobaev, M.M.; Shaldybin, L.C.; Matsaberidze, G.V.; Merkusheva, I.V.; Nadtochiy, E.V.; Khokhlova, I.G.; Sharpilo, L.D. Keys to the helminths of rodents in the USSR fauna. In Nematodes and Acanthocephalans; Nauka: Moscow, Russia, 1979; pp. 3-272.

48. Genov, T. Helminths of Insectivores and Rodents in Bulgaria; Bulgarian Academy of Sciences: Sofia, Bulgaria, $1984 ;$ pp. 3-348.

49. Makarikov, A.A.; Tkach, V.V. Two new species of Hymenolepis (Cestoda: Hymenolepididae) from Spalacidae and Muridae (Rodentia) from eastern Palearctic. Acta Parasitol. 2013, 58, 37-49. [CrossRef] [PubMed]

50. Haukisalmi, V. A taxonomic revision of the genus Anoplocephaloides Baer, 1923 sensu Rausch (1976), with the description of four new genera (Cestoda: Anoplocephalidae). Zootaxa 2009, 2057, 1-31. 
51. Haukisalmi, V.; Hardman, L.M.; Henttonen, H. Taxonomic review of cestodes oft the genus Catenotaenia Janicki, 1904 in Eurasia and molecular phylogeny of the Catenotaeniidae (Cyclophyllidea). Zootaxa 2010, 2489, 1-33. [CrossRef]

52. Dawes, B. The Trematode; Cambridge University Press: Cambridge, UK, 1968; pp. 3-660.

53. Sharpilo, V.P.; Iskova, N.P. Fauna of Ukraine. Trematodes. Plagiorchiata; Issue 3; Naukova Dumka: Kiev, Ukraine, 1989; Volume 34, pp. 3-280.

54. Kirillov, A.A.; Kirillova, N.Y.; Chikhlyaev, I.V. Trematodes of Land Vertebrates of Middle Volga Region; Cassandra: Togliatti, Russia, 2012; pp. 3-329.

55. Feliu, C.; Spakulova, M.; Casanova, J.C.; Renaud, F.; Morand, S.; Hugot, J.P.; Santalla, F.; Durand, P. Genetic and morphological heterogeneity in small rodent whipworms in southwestern Europe: Characterization of Trichuris muris and description of Trichuris arvicolae n. sp. (Nematoda: Trichuridae). J. Parasitol. 2000, 86, 442-449. [CrossRef]

56. Fauna Europaea. Available online: https:/ / fauna-eu.org/ (accessed on 12 September 2021).

57. Global Cestode Database. Available online: http:/ / tapewormdb.uconn.edu (accessed on 12 September 2021).

58. Magurran, A.E. Measuring Biological Diversity; Blackwell Publishing: Oxford, UK, 2004; pp. 3-256.

59. Bakanov, A.I. Quantitated Estimation of Dominance in Ecological Communities; The Manuscript Was Deposited in All-Union Institute of Scientific and Technical Information (VINITI, Russia) 08.12.1987, No. 8593-B87; IBIW RAS Publishing: Borok, Russia, 1987; pp. 3-64.

60. Hammer, O.; Harper, D.A.T.; Ryan, P.D. PAST: Paleontological statistics software package for education and data analysis. Version 2.16. Palaeontol. Electron. 2001, 4,9.

61. Lavikainen, A.; Iwaki, T.; Nakao, M.; Konyaev, S.V. Genetic diversity of the cryptic Hydatigera taeniaformis complex. In New Knowledge for Parasites. Parasitological Studies in Siberia and the Far East, Proceedings of the V Interregional Conference, Novosibirsk, Russia, 14-16 September 2015; Yurlova, N.I., Konyaev, S.V., Eds.; Garamond: Novosibirsk, Russia, 2015; pp. $65-66$.

62. Lavikainen, A.; Iwaki, T.; Haukisalmi, V.; Konyaev, S.V.; Casiraghi, M.; Dokuchaev, N.E.; Galimberti, A.; Haljian, A.; Henttonen, H.; Ichikawa-Seki, M.; et al. Reappraisal of Hydatigera taeniaeformis (Batsch, 1786) (Cestoda: Taeniidae) sensu lato with description of Hydatigera kamiyai n. sp. Int. J. Parasitol. 2016, 46, 361-374. [CrossRef]

63. Haukisalmi, V.; Hardman, L.M.; Henttonen, H.; Laakkonen, J.; Niemimaa, J.; Hardman, M.; Gubanyi, A. Molecular systematics and morphometrics of Anoplocephaloides dentata (Cestoda, Anoplocephalidae) and related species in voles and lemmings. Zool. Scr. 2009, 38, 199-220. [CrossRef]

64. Haukisalmi, V.; Wickstrom, L.M.; Henttonen, H.; Hantula, J.; Gubanyi, A. Molecular and morphological evidence for multiple species within Paranoplocephala omphalodes (Cestoda, Anoplocephalidae) in Microtus voles (Arvicolinae). Zool. Scr. 2004, 33, 277-290. [CrossRef]

65. Vlasenko, P.; Abramov, S.; Bugmyrin, S.; Dupal, T.; Fomenko, N.; Gromov, A.; Zakharov, E.; Ilyashenko, V.; Kabdolov, Z.; Tikunov, A.; et al. Geographical distribution and hosts of the cestode Paranoplocephala omphalodes (Hermann, 1783) Lühe, 1910 in Russia and adjacent territories. Parasitol. Res. 2019, 118, 3543-3548. [CrossRef] [PubMed]

66. Haukisalmi, V.; Hardman, L.M.; Foronda, P.; Feliu, C.; Laakkonen, J.; Niemimaa, J.; Lehtonen, J.T.; Henttonen, H. Systematic relationships of hymenolepidid cestodes of rodents and shrews inferred from sequences of $28 \mathrm{~S}$ ribosomal RNA. Zool. Scr. 2010, 39, 631-641. [CrossRef]

67. Montgomery, S.S.J.; Montgomery, W.I.; Dunn, T.S. Biochemical, physiological and morphological variation in unarmed hymenolepids (Eucestoda: Cyclophyllidea). Zool. J. Linn. Soc. 1987, 91, 293-324. [CrossRef]

68. Kostadinova, A.; Gibson, D.I.; Biserkov, V.; Ivanova, R. A quantitative approach to the evaluation of the morphological variability of two echinostomes, Echinostoma miyagawai lshii, 1932 and, E. revolutum (Frolich, 1802), from Europe. Syst. Parasitol. 2000, 45, 1-15. [CrossRef]

69. Kostadinova, A.; Gibson, D.I.; Biserkov, V.; Chipev, N. Re-validation of Echinostoma miyagawai Ishii, 1932 (Digenea: Echinostomatidae) on the basis of the experimental completion of its life-cycle. Syst. Parasitol. 2000, 45, 81-108. [CrossRef]

70. Faltynkova, A.; Georgieva, S.; Soldanova, M.; Kostadinova, A. A re-assessment of species diversity within the 'revolutum' group of Echinostoma Rudolphi, 1809 (Digenea: Echinostomatidae) in Europe. Syst. Parasitol. 2015, 90, 1-25. [CrossRef] [PubMed]

71. Shaykenov, B. Helminths in Rodents from Kazakhstan; Nauka: Alma-Ata, Kazakhstan, 1981; pp. 3-172.

72. Cutillas, C.; Oliveros, R.; Rojas, M.; Guevarra, D.C. Determination of Trichuris muris from murid hosts and T. arvicolae (Nematoda) from arvicolid rodents by amplification and sequestration of the ITS1-5.8SITS2 segment of the ribosomal DNA. Parasitol. Res. 2002, 88, 574-582. [CrossRef] [PubMed]

73. Callejon, R.; de Rojas, M.; Feliu, C.; Balao, F.; Marrugal, A.; Henttonen, H.; Guevara, D.; Cutillas, C. Phylogeography of Trichuris populations isolated from different Cricetidae rodents. Parasitology 2012, 139, 1795-1812. [CrossRef] [PubMed]

74. Quentin, J.C. Morphogenese larvarie du spiruride Mastophorus muris (Gmelin, 1790). Ann. Parasitol. Hum. Comp. 1970, 45, 839-855. [CrossRef]

75. Kozlov, D.P. Keys to Helminths of Carnivores of the USSR; Nauka: Moscow, Russia, 1977; pp. 3-275.

76. Akbaev, M.S.; Vodyanov, A.A.; Kosminkov, N.E. Parasitology and Invasive Diseases of Animals; Kolos: Moscow, Russia, 1998; pp. 3-743.

77. Kirillova, N.Y.; Kirillov, A.A. Ecological analysis of helminth fauna of mouse rodents of the Samarskaya Luka. Proc. Samara Sci. Center RAS 2005, 4, 261-275. 
78. Roberts, M.; Rodrigo, A.; McArdle, B.; Charleston, W.A.G. The effect of habitat on the helminth parasites of an island population of the Polynesian rat (Rattus exularis). J. Zool. 1992, 227, 109-125. [CrossRef]

79. Arneberg, P. Host population density and body mass as determinants of species richness in parasite communities: Comparative analyses of directly transmitted nematodes of mammals. Ecography 2002, 25, 88-94. [CrossRef]

80. Anikanova, V.S.; Ieshko, E.P.; Bugmyrin, S.V.; Borodina, K.A. Peculiarities of biotopic distribution of cestodes from the common shrew Sorex araneus in Southern Karelia. Parasitologiia 2003, 37, 479-487.

81. Kirillova, N.Y.; Kirillov, A.A. Influence of the population density of the host (mouse rodents) on its helminth fauna. Proc. Samara Sci. Center RAS 2006, 8, 548-555.

82. Torres, J.; Miquel, J.; Casanova, J.C.; Ribas, A.; Feliu, C.; Morand, S. Endoparasite species richness of Iberian carnivores: Influences of host density and range distribution. Biodivers. Conserv. 2006, 15, 4619-4632. [CrossRef]

83. Kirillova, N.Y.; Kirillov, A.A. Island isolation influence on parasite fauna of murine rodents. Proc. Samara Sci. Center RAS 2009, 11, 119-126.

84. Rosalino, L.M.; Santos, M.J.; Fernandes, C.; Santos-Reis, M. Biogeographical region and host trophic level determine carnivore endoparasite richness in the Iberian Peninsula. Parasitology 2011, 138, 758-765. [CrossRef]

85. Froeschke, G.; Matthee, S. Landscape characteristics influence helminth infestations in a peri-domestic rodent-Implications for possible zoonotic disease. Parasites Vectors 2014, 7, 393. [CrossRef]

86. Parshina, O.Y.; Kalmykov, A.P.; Ivanov, V.M.; Semenova, N.N. Helminth fauna in rodents of family Muridae Illiger, 1811 in biogeocoenoses of Astrakhan region. In Biota and Soil Diversity of Nothern and Central Asia, Proceedings of II International Conference, Volume 2, Ulan-Ude, Russia, 20-25 June 2011; Buryatian Scientific Center of Siberian Branch of RAS: Ulan-Ude, Russia, 2011; pp. 87-90.

87. Bugmyrin, S.V.; Korosov, A.V.; Bespyatova, L.A.; Ieshko, E.P. Helminth fauna of the bank vole Myodes glareolus (Schreber, 1780) in the Kizhi archipelago. Parasitologiia 2015, 49, 61-71.

88. Kirillova, N.Y.; Kirillov, A.A.; Ruchin, A.B.; Trukhachev, M.V. Helminth fauna of Microtus cf. arvalis (Rodentia, Cricetidae) in Russia and adjacent countries. Biodiversitas 2020, 21, 1961-1979. [CrossRef] 